\title{
Microcystin production by cyanobacteria in the Mwanza Gulf (Lake Victoria, Tanzania)
}

\author{
Baraka C. Sekadende ${ }^{1}$, Thomas J. Lyimo ${ }^{2}$ \& Rainer Kurmayer ${ }^{3, *}$ \\ ${ }^{1}$ Tanzania Fisheries Research Institute, P.O. Box 90, Kigoma, Tanzania \\ ${ }^{2}$ Botany Department, University of Dar es Salaam, P.O. Box 35060, Dar es Salaam, Tanzania \\ ${ }^{3}$ Austrian Academy of Sciences, Institute for Limnology, Mondseestrasse 9, A-5310 Mondsee, Austria \\ (*Author for correspondence: Tel.: 0043-6232-312532; Fax:0043-6232-3578; E-mail: rainer.kurmayer@oeaw.ac.at)
}

Received 5 March 2004; in revised form 28 July 2004; accepted 30 November 2004

Key words: eutrophication, phytoplankton composition, algal biovolume, nutrients, toxin analysis, health risk

\begin{abstract}
In order to investigate the potential for microcystin (MC) production by cyanobacteria in the Mwanza Gulf (Lake Victoria, Tanzania), nutrients, phytoplankton and microcystins were sampled inshore ( $3 \mathrm{~m} \mathrm{depth}$ ) and offshore (18 m depth) from May to August 2002. Significant differences in soluble reactive phosphorus (SRP) and nitrate concentrations between offshore and inshore indicated eutrophication via terrestrial runoff. Though the concentrations of SRP and nitrate ranged between 36-127 and 35-726 $\mu \mathrm{g}^{-1}$ each, the phytoplankton biovolume was generally low. The phytoplankton community was dominated by diatoms (Nitzschia acicularis), a number of cyanobacterial species (Aphanocapsa sp., Anabaena sp., Planktolyngbya spp., Microcystis sp.) and cryptomonads. The water column was completely mixed and Nitzschia peaked in abundance during July. All cyanobacteria were low in abundance during the entire study period $\left(0.1-1.6 \mathrm{~mm}^{3} 1^{-1}\right)$. Microcystins were analysed using high performance liquid chromatography coupled with diode array detection High Performance Liquid Chromatography with Diode Array Detection (HPLC-DAD) and in most samples no microcystins were detected. The highest concentration of [Asp $\left.{ }^{3}\right]-$ MC-RR was found in open water at the surface on July 2nd, $2002\left(1 \mu \mathrm{g}^{-1}\right)$. MC concentrations did not pose a potential health risk in the Mwanza Gulf during the study period, however, it is possible that the period of higher cyanobacterial biovolumes has been missed during the sampling period of this study.
\end{abstract}

\section{Introduction}

The most abundant toxins that are found in the freshwaters of the temperate region are the microcystins. Microcystins are produced by a number of planktonic cyanobacterial genera (Sivonen \& Jones, 1999). Microcystins are cyclic heptapeptides and share the common structure cyclo $\left(-\mathrm{D}-\mathrm{Ala}^{(1)}-\mathrm{X}^{(2)}-\mathrm{D}-\mathrm{MeAsp}{ }^{(3)}-Z^{(4)}-\mathrm{Adda}^{(5)}-\mathrm{D}-\right.$ $\left.\mathrm{Glu}^{(6)}-\mathrm{Mdha}^{(7)}\right)$, where $\mathrm{X}$ and $\mathrm{Z}$ are variable L-amino acids (e.g. microcystin (MC)-LR refers to leucine and arginine in the variable positions of this peptide), $\mathrm{D}$-MeAsp is $\mathrm{D}$-erythro- $\beta$-iso-aspartic acid, Adda is $(2 S, 3 S, 8 S, 9 S)$-3-amino-9-methoxy2,6,8-trimethyl-10-phenyldeca-4,6-dienoic acid, and Mdha is $N$-methyl-dehydroalanine (Carmichael et al., 1988). Toxicity is mediated through the active transport of MC into hepatocytes by the bile acid organic anion transport system. This is followed by the inhibition of eukaryotic serine/threonine protein phosphatases 1 and 2A (Kuiper-Goodman et al., 1999). After the ingestion of MC-containing cyanobacteria, acute poisoning leading to death from massive hepatic haemorrhage has been reported in animals. A number of incidents of human illness have been attributed to microcystins in 
drinking water or at recreational sites (Kuiper-Goodman et al., 1999). Chronic ingestion of sublethal doses has been further epidemiologically linked to primary liver cancer and colorectal cancer in humans (Zhou et al., 2002).

Lake Victoria and its catchments have undergone eutrophication over the last three decades (Verschuren et al., 2001). Based on microscopical numeration of phytoplankton, increased cyanobacterial abundances were reported (Ochumba \& Kibaara, 1989; Lung'aiya et al., 2000). In 1984 massive fish kills were observed in the Nyanza Gulf of Lake Victoria, Kenya, which coincided with the occurrence of cyanobacteria (Ochumba, 1990). No efforts were made to identify microcystins. In the Lake Victoria region, $4 \%$ of all households in the Kisumu district have been estimated to use lake water for drinking purposes (Some \& Omurwa, 1994). This study aimed at assessing the phytoplankton growth in relation to environmental factors, assessing whether the potential MC producers occur in the Mwanza Gulf and whether or not they produce MC.

\section{Materials and methods}

Sampling was performed weekly from May 21st until August 20th, 2002 in the Mwanza Gulf of Lake Victoria (Tanzania, surface $500 \mathrm{~km}^{2}$, max. depth $18 \mathrm{~m})$. One sampling site was inshore $(3 \mathrm{~m}$ depth, $0230.555 \mathrm{~S}, 3253.863 \mathrm{E}$ ) near the confluence where the Mirongo River meets the lake. The river is known to carry municipal wastes from the town of Mwanza and from Bugando, the main governmental hospital. The other sampling site was offshore (18 m, $0229.384 \mathrm{~S}, 3235.210 \mathrm{E})$, which is thought to be less influenced by eutrophication.

A 41 Van Dorn water sampler was used to obtain samples at a depth of $1 \mathrm{~m}$ and to integrate samples by collecting 21 at $1 \mathrm{~m}$ intervals from the surface to the sediment. In the laboratory, samples for nutrient analysis were filtered using a water jet vacuum pump at low pressure through $0.45 \mu \mathrm{m}$ membrane filters (VWR, Austria). For the analysis of microcystins 0.51 of each sample was filtered onto glass fibre filters $(\mathrm{GF} / \mathrm{C}$, Whatman, UK). The filters were dried at $60{ }^{\circ} \mathrm{C}$ for several days and stored dry in a desiccator until analysis. The soluble reactive phosphorus (SRP) was determined using the ammonium molybdate method (Wetzel \& Likens, 2000). Nitrate $\left(\mathrm{NO}_{3}-\mathrm{N}\right)$ was determined using the sodium-salycilate method (Müller \& Wiedemann, 1955). The ammonium $\left(\mathrm{N}-\mathrm{NO}_{4}\right)$ analysis was based on the formation of indophenol blue (Krom, 1982). Due to technical problems only the samples from the months of July and August were analysed for ammonia.

Phytoplankton was identified using the standard literature and the identification of cyanobacteria was achieved using the taxonomical criteria of Talling (1987) and Komarek \& Kling (1991). At least 400 specimens of the few dominant species were counted from Lugol fixed samples following the methods of Utermöhl (1958). The species were counted as single cells (Anabaena, Microcystis, Nitzschia), filaments (Planktolyngbya) or colonies (Aphanocapsa). Measurements of cell length and width were determined from 20 randomly selected specimens from the dominant species and the volumes were calculated by assuming a geometric shape. The biovolume was then calculated by multiplying the mean cell volume by cell density (Wetzel \& Likens, 2000).

The extraction of microcystins was performed according to Fastner et al. (1998) and the analysis was done using high performance liquid chromatography with diode array detection (HPLC-DAD) as described (Kurmayer et al., 2003). Microcystins were identified by their characteristic absorption spectra (original spectrum and first order derivative) and retention times (Fastner et al., 1999). In addition, dried HPLCfractions of putative MCs were analysed for their positive ion mass spectra using a matrix assisted laser desorption-time of flight mass spectrometer (MALDI-TOF MS) as described previously (Kurmayer et al., 2004). MC variants were identified by way of PSD fragment structure analysis (Fastner et al., 1999).

\section{Results and discussion}

The offshore water temperature (at $1 \mathrm{~m}$ depth) decreased slightly from 24.8 to $23.9^{\circ} \mathrm{C}$ throughout the sampling period. The water column was never stratified. The decline in water temperature during the dry season may have resulted from the upwelling of cold water into the gulf from the deep 
layers of the lake due to strong seasonal southeastern winds (Akiyama et al., 1977). The $\mathrm{pH}$ values ranged between 7.4 and 7.8 during the study period at both stations. Secchi depth (Fig. 1(a)) was significantly lower inshore $(0.95-1.9 \mathrm{~m})$ than offshore (1.1-3.4 m, Mann-Whitney Rank Sum Test, $p=0.002, n=12)$. SRP and nitrate concentrations ranged between 36-127 and 35-726 $\mu \mathrm{g} \mathrm{1^{-1 }}$ each, and it is concluded that phytoplankton growth was not limited by SRP or nitrate. The maximum nitrate concentration $\left(726 \mu \mathrm{g} \mathrm{l}^{-1}\right)$ was recorded inshore in May directly after the rainy season (Fig. 1(b), (c)). Throughout the study period SRP and nitrate concentrations were significantly higher inshore than offshore (Mann-Whitney Rank Sum Test, $p=0.036, n=13$ for SRP and $p<0.001$, $n=12$ for nitrate). The earlier investigations by Akiyama et al. (1977) showed much lower SRP values $\left(<15 \mu \mathrm{g}^{-1}\right)$ and nitrate concentrations (mostly $<5 \mu \mathrm{g} \mathrm{l}^{-1}$ ). The results correspond to the general view of ongoing eutrophication in Lake Victoria throughout the last few decades. The higher values of SRP inshore as compared to the open water could be due to the contamination of the water by phosphate rich detergents since activities such as bathing and washing around the lakeshores were observed during the period of investigation. The highest nitrate concentrations that were found during the months of May and June immediately after the rainy season may be attributed to terrestrial run off as has been suggested by Ochumba \& Kibaara (1989).
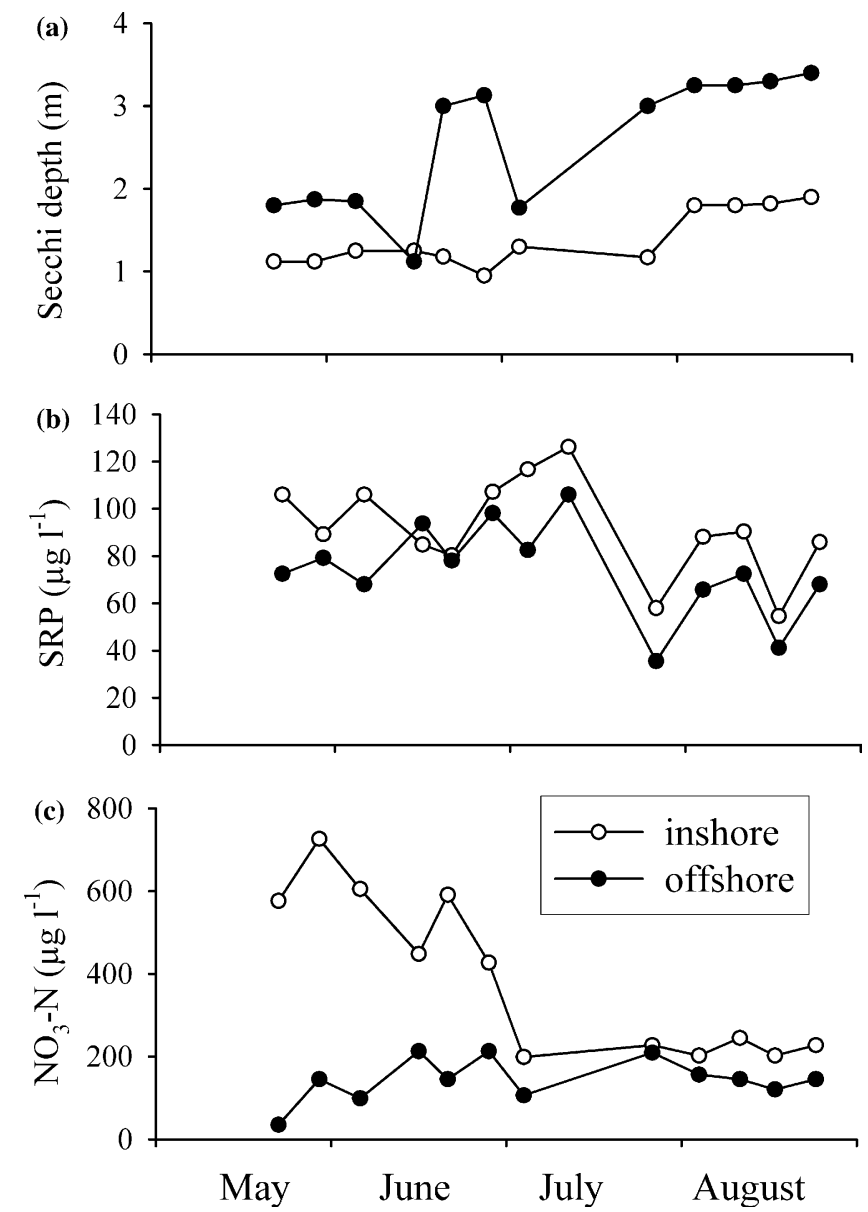

Figure 1. (a) Secchi disks readings during the sampling period inshore (white) and offshore (black) in Mwanza Gulf (Tanzania) from May until August 2002. (b) Concentrations of soluble reactive phosphorous (SRP). (c) Concentrations of nitrate $\left(\mathrm{NO}_{3}-\mathrm{N}\right)$ during the same period. 
In contrast to SRP and nitrate, the ammonium concentrations were significantly higher in the open water $\left(12.6-54.5 \mu \mathrm{g}^{-1}\right)$ than inshore (0.4-11.6 $\mu \mathrm{g} \mathrm{1}^{-1}$, Mann-Whitney Rank Sum Test, $p=0.008, n=5)$. The oxidation of $\mathrm{NH}_{4}-\mathrm{N}$ to $\mathrm{NO}_{3}-\mathrm{N}$ depends on the availability of dissolved oxygen, however oxygen was not limiting over the total water column (data not shown). Consequently, the upwelling phenomena of water from deeper layers with low oxygen values may not only cause a mixed water column water column, but also contribute to the higher $\mathrm{NH}_{4}-\mathrm{N}$ concentration offshore.

In general algal biovolume was low over the entire study period $\left(0.6-8.1 \mathrm{~mm}^{3} \mathrm{l}^{-1}\right)$. Bacillariophyceae (Nitzschia acicularis (Kützing) W. Smith and undetermined centric diatoms being the most abundant species) contributed most of the biovolume of total phytoplankton with biovolumes ranging from $0.2-7.5 \mathrm{~mm}^{3} \mathrm{l}^{-1}$ (Fig. 2). $N$. acicularis dominated the phytoplankton biovolume frequently at both stations (5-90\%). Cyanobacterial biovolume was higher at the beginning of the sampling period in May, decreased until June and started to increase again towards July. The genus Planktolyngbya contributed the largest proportion to total phytoplankton (3-37\%). P. undulata J. Komarék \& H. Kling and $P$. circumcreta G.S. West were the most abundant. Aphanocapsa sp. made up $1-39 \%$ of the total phytoplankton biovolume. The proportions of the genera known to produce microcystins Microcystis and Anabaena were $0-5 \%$ and $0-2.5 \%$, each. Cryptomonads were mainly composed of Cryptomonas sp. in the size class $<10 \mu \mathrm{m}$ and made up $0-30 \%$ of the total phytoplankton. In general there were no significant differences in phytoplankton composition between the offshore and inshore and no accumulation of cyanobacteria was observed in the surface layers when compared with the total water column.

In contrast to the dominance of $N$. acicularis, Akiyama et al. (1977) found Melosira, Nitzschia and Surirella much more abundant in the Mwanza gulf. These results confirm the general species change in the phytoplankton composition in Lake Victoria (e.g. Verschuren et al., 2001). Within cyanobacteria, Anabaena, Microcystis, Merismopedia, Aphanocapsa and Planktolyngbya not only have been found in this study but have also been reported from earlier investigations (Talling, 1966; Akiyama et al., 1977; Komarek \& Kling, 1991). Notably the cyanobacterial cell numbers were rather low, although environmental factors in general were found to be suitable in favour of the growth of cyanobacteria. This indicates that the algal growth was probably limited by other factors apart from $\mathrm{SRP}, \mathrm{NO}_{3}-\mathrm{N}$ and temperature. The mean depth of the lake is $40 \mathrm{~m}$ and it is speculated that the prevalence of the strong seasonal southeastern winds not only prevented the water column from stratifying down to $40 \mathrm{~m}$, but also kept the average light dose of the individual cell to a limiting level.

In most samples, no microcystins were detected. However in one sample from offshore on July 2nd, 2002 (at the surface) a MC with a retention time of $14.21 \mathrm{~min}$ was detected. The spectrum showed a close match with [Asp ${ }^{3}$ microcystin-RR available from the spectrum library (data not shown). MALDI-TOF MS analysis of the fractionated peak also identified the MC as [D-Asp ${ }^{3}$ ]-MC-RR (molecular weight 1024 dalton) and with regard to the retention time in HPLC the MC was determined as $\left[\mathrm{Asp}^{3}\right.$, $\mathrm{Dhb}^{7}$ ]-MC-RR. The concentration was $992 \mathrm{ng}$ MC-LR equivalents $1^{-1}$. Both genera Anabaena and Microcystis have been shown to produce MC (Sivonen \& Jones, 1999). Future work should also include the determination of MC cell quotas both from field samples and from isolates grown in culture. To exclude a possible bias due to the selective cultivation of specific genotypes (i) colonies may be directly isolated from the field and analysed using MALDI-TOF (Kurmayer et al., 2002) and/or (ii) samples with a higher biovolume of either Microcystis or Anabaena may be collected over the season and analysed for MC production. Talling (1966) observed the occurrence of the cyanobacterial maximum in Lake Victoria during November and January and Akiyama et al. (1977) observed that Anabaena cell numbers were extremely high in November 1973 at the surface, i.e. 5.6 $\times 10^{8}$ cells $1^{-1}$ as compared to $1.3 \times 10^{6}$ cells $1^{-1}$ observed on July 24 th at the surface in open water during this study. During the period from November to January, the water is calmer than during the period from May until August and cyanobacteria should be able to accumulate at 


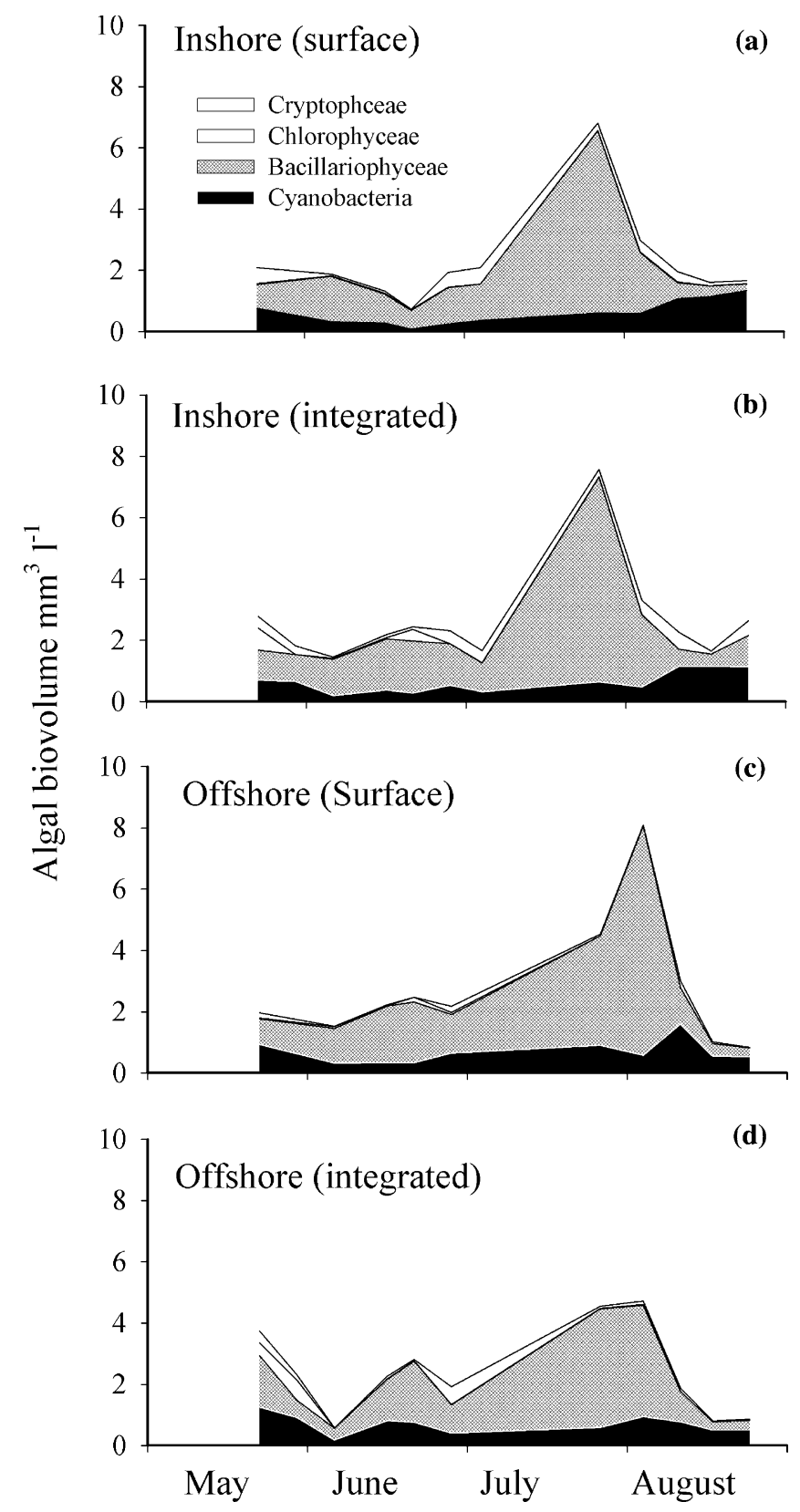

Figure 2. Phytoplankton biovolume and major algal composition at the surface inshore (a) and offshore (b) and integrated over the water column inshore (c) and offshore (d) in the Mwanza Gulf from May until August 2002. Only cyanobacteria (black), diatoms (hatched) and cryptomonads (white) contributed significantly to algal biovolume.

the surface due to their natural buoyancy and gain a selective advantage compared to other phytoplankton. It is possible that the period of higher cyanobacterial biovolumes has been missed during the sampling period of this study.

\section{Acknowledgements}

The data reported in this study originated from the MSc thesis submitted by B. C. S. to the International Institute for Infrastructural Hydraulic and 
Environmental Engineering (IHE, Delft). We are grateful to Gerold Winkler and Sabine Wanzenböck for their outstanding organisation of the IPGL course at the Limnological Institute in Mondsee, Austria. This study was funded by the Austrian Academy of Sciences and by The Netherlands Fellowship Programme (NFP). We are grateful to one anonymous referee for his helpful suggestions. Special thanks goes to the centre director of TAFIRI (Tanzania Fisheries Research Institute) Mwanza, Mr Katunzi for making the facilities and accommodation at the institute available. Thanks to Wabeya and Jongo for their assistance during the fieldwork. B. C. S. would like to mention Ms Joyce Nyaugu, Angel, Sabintina, Mr Semvu, Sabuni, Mussa who made her stay rather comfortable in Mwanza. We are grateful to Jutta Fastner for the MALDI-TOF identification of microcystin.

\section{References}

Akiyama, T., A. Kajumulo \& S. Olsen, 1977. Seasonal variations of plankton and physicochemical condition in Mwanza Gulf, Lake Victoria. Bulletin of Freshwater Fisheries Research Laboratory 27: 49-60.

Carmichael, W. W., V. Beasly, D. L. Bunner, J. N. Eloff, I. Falconer, P. Gorham, K.-I. Harada, T. Krishnamurty, Y. Min-Juan, R. E. Moore, K. Rinehart, M. Runnegar, O. M. Skulberg \& M. Watanabe, 1988. Naming cyclic heptapeptide toxins of cyanobacteria (blue-green algae). Toxicon 26: 971-973.

Fastner, J., M. Erhard, W. W. Carmichael, F. Sun, K. L. Rinehart, H. Rönicke \& I. Chorus, 1999. Characterization and diversity of microcystins in natural blooms and strains of the genera Microcystis and Planktothrix from German freshwaters. Archiv für Hydrobiologie 145: 147-163.

Fastner, J., I. Flieger \& U. Neumann, 1998. Optimised extraction of microcystins from field samples - a comparison of different solvents and procedures. Water Research 32: 3177-3181.

Komarek, J. \& H. Kling, 1991. Variation in six planktonic cyanophyte genera in Lake Victoria (East Africa). Algological Studies 61: 21-45.

Krom, M. D., 1982. Spectrophotometric determination of ammonia: a study of a modified Bertholet reaction using salicylate and dichlorisocyanurate. The Analyst 105: 305-316.

Kuiper-Goodman, T., I. Falconer \& J. Fitzgerald, 1999. Human health aspects. In Chorus, I. \& J. Bartram (eds),
Toxic Cyanobacteria in Water, A Guide to Their Public Health Consequences, Monitoring and Management. WHO, E \& FN Spon, London: 113-153.

Kurmayer, R., G. Christiansen \& I. Chorus, 2003. The abundance of microcystin-producing genotypes correlates positively with colony size in Microcystis and determines its microcystin net production in Lake Wannsee. Applied and Environmental Microbiology 69: 787-795.

Kurmayer, R., G. Christiansen, J. Fastner \& T. Börner, 2004. Abundance of active and inactive microcystin genotypes in populations of the toxic cyanobacterium Planktothrix spp., Environmental Microbiology 6: 831-841.

Kurmayer, R., E. Dittmann, J. Fastner \& I. Chorus, 2002. Diversity of microcystin genes within a population of the toxic cyanobacterium Microcystis spp. in Lake Wannsee (Berlin, Germany), Microbial Ecology 43: 107-118.

Lung'ayia, H. B. O., A. M’Harzi, M. Tackx, J. Gichuki \& J. J. Symoens, 2000. Phytoplankton community structure and environment in the Kenyan waters of lake Victoria. Freshwater Biology 43: 529-543.

Müller, R. \& O. Wiedemann, 1955. Die Bestimmung des Nitrations im Wasser. Vom Wasser 22: 247-271.

Ochumba, P. B. O., 1990. Massive fish kills within the Nyanza Gulf of lake Victoria, Kenya. Hydrobiologia 208: 93-99.

Ochumba, P. \& D. Kibaara, 1989. Observations on blue-green algal blooms in the open waters of Lake Victoria, Kenya. African Journal of Ecology 27: 23-34.

Sivonen, K. \& G. Jones, 1999. Cyanobacterial toxins. In Chorus, I. \& J. Bartram (eds), Toxic Cyanobacteria in Water, A Guide to Their Public Health Consequences, Monitoring and Management. WHO, E \& FN Spon, London: 41-112.

Some, E. \& T. Omurwa, 1994. Seasonality and community's satisfaction with sources of domestic water in the Lake Victoria basin. Eastern African Medical Journal 71: 39-41.

Talling, J. F., 1987. The phytoplankton of Lake Victoria (East Africa). Archiv für Hydrobiologie Beiheft Ergebnisse der Limnologie 25: 229-256.

Talling, J., 1966. The annual cycle of stratification and phytoplankton growth in Lake Victoria (East Africa). Internationale Revue der gesamten Hydrobiologie 51: 545-621.

Utermöhl, H., 1958. Zur Vervollkommnung der quantitativen Phytoplanktonmethodik. Mitteilungen der Internationalen Vereinigung für Theoretische und Angewandte Limnologie 2: $1-38$.

Verschuren, D., T. C. Johnson, H. J. Kling, D. N. Edgington, P. R. Leavitt, E. T. Brown, M. R. Talbot \& R. E. Hecky, 2001. History and timing of human impact on Lake Victoria, East Africa. Proceedings of The Royal Society of London series B 269: 289-294.

Wetzel R. A. \& G. E. Likens, 2000. Limnological analysis. 3rd edn. Springer Verlag. New York.

Zhou, L., H. Yu \& K. Chen, 2002. Relationship between microcystin in drinking water and colorectal cancer. Biomededial and Environmental Sciences 15: 166-171. 